\title{
Biyoplastiklerin Biyodegradasyonu
}

\author{
Özge KÖKSAL ${ }^{a}$, Bilge AYDIN ER ${ }^{a}$, Yüksel ARDALI ${ }^{a^{*}}$, Mustafa SA $\breve{G L A M}$ \\ ${ }^{a}$ Ondokuz Mayıs Üni., Mühendislik Fak., Çevre Müh. Böl.,Samsun \\ ${ }^{b}$ Ondokuz Mayıs Üni., Ziraat Fak., Toprak Bilimi ve Bitki Besleme Böl., Samsun
}

\author{
$\ddot{O} \mathbf{z}$
}

Günümüze bakıldığında plastikler yarı sentetik veya sentetik bileşiklerden yapılan, kolay şekil verilebilen, üretiminin kolay olması, suya, kimyasal maddelere ve çevresel değişimlere (1şık, sıcaklık vb.) karşı duyarlı olması sebebiyle kullanımları oldukça geniş bir yer tutmaktadır. Üretime paralel olarak artış gösteren plastik atık kirliliği de hem çevreyi hem de fosil yakıt kaynaklarını önemli ölçüde tehdit etmektedir. Gelişen çevre bilinci ile birlikte daha çevre dostu malzemeler olan biyoplastiklerin bu konuda önemli bir alternatif olduğu düşünülmektedir. Biyoplastikler genel tanımı, bitkisel katı ve sıvı yağlar, bitki nişastaları veya mikroorganizmalar gibi yenilenebilir biyolojik kaynaklardan elde edilen plastikler olarak ifade edilmektedir. Alternatif olarak biyoplastiklerin tercihi ile yenilenebilir kaynakların artışının da sürdürülmesi amaçlanmaktadır. Tarımsal atıklar gibi yenilenebilir kaynakların tüketilmesi ve farklı çevrelerde biyolojik olarak ayrışması biyoplastiklerin daha kolay benimsenmesini sağlamıştır. Biyoplastiklerin biyodegradasyonu sahip oldukları fiziksel ve kimyasal yapılarından kaynaklanmaktadır. Biyoplastiklerin çevre dostu ürünler olması, kullanılan teknolojilere uyum sağlamaları nedeniyle kullanımlarındaki artış ile gelecekte plastiklerin yerini alacağı düşünülmektedir. $\mathrm{Bu}$ çalışmada, biyoplastiklerin biyobozunurluk durumları incelenmiştir.

Anahtar kelimeler: Plastikler, biyoplastik, biyodegradasyon, biyobozunur plastik.

\section{Biodegradation of Bioplastics}

\section{Abstract}

Looking at today, plastics are widely used because they are made of semisynthetic or synthetic compounds, are easily shaped, easy to produce and sensitive to water, chemicals and environmental changes (light, temperature, etc.). Plastic waste pollution, which increases in parallel with production, poses a significant threat to both the environment and fossil fuel sources. Bioplastics, which are more environmentally friendly materials with developing environmental awareness, are considered to be an important alternative in this regard. The general definition of bioplastics is referred to as plastics obtained from renewable biological sources such

\footnotetext{
* Sorumlu Yazar: : ORCID ID: orcid.org/ 0000-0003-1648-951X e-mail: yuksel.ardali@omu.edu.tr
}

Received: 20.12.2018

Accepted: 03.12.2019 
as vegetable fats and oils, plant starches or microorganisms. Alternatively, the preference of bioplastics is intended to sustain the increase of renewable resources. Consumption of renewable resources such as agricultural wastes and biodegradation in different environments have made bioplastics easier to adopt. Biodegradation of bioplastics is due to their physical and chemical structure. Bioplastics are considered to be environmentally friendly products and adapt to the technologies used, thus increasing their usage in the future.

Keywords: Plastics, bioplastic, biodegradation, biodegradable plastic.

\section{Giriş}

Plastikler günümüzde özellikle ambalaj uygulamalarında en yaygın kullanılan polimerlerdir [1]. Plastik kullanımı, nüfus artışına ve teknolojik gelişmelere bağlı olarak gün geçtikçe artmakta ve insan hayatında yeri sürekli genişlemektedir. Kullanım alanlarının her geçen gün daha da yaygınlaşıyor olması, plastiklerin diğer kullanılan materyallere göre işlenmesinin daha kolay olmasından kaynaklanmaktadır [23]. Plastiklerin uygulama alanlarının genişliği endüstriyel alanda bir avantaj olmakla birlikte dünyanın her yerinde her yıl büyük miktarlarda plastik atıkların oluşmasına neden olmaktadır.

Dolayısıla bu atıkların yönetimi büyük öneme sahiptir ve özellikle geri dönüşüm ve yeniden kullanımın yeterli oranda yapılmaması nedeni ile kentsel depolama alanlarına gönderilen plastikler ciddi çevre sorunlarına yol açmaktadır [1].

Dünyada her yıl yaklaşık 34 milyon ton plastik atık çevreye atılmaktadır ve bu atık miktarının \%93'ü depolama alanlarına ve okyanusa gitmektedir [24]. Avrupa Birliği $(\mathrm{AB})$ 'ne üye ülkelerin bazıları depolama konusuna yasak getirseler de plastik atığın yaklaşık \%50 'si depolama alanlarına atılmaktadır. Almanya, Hollanda, İsveç, Danimarka ve Avusturya plastik atıkların \%80100 arasinda geri kazanılmasinda başarılı olmasına karşın Avrupa'da geri kazanımın ortalaması yalnızca $\% 28^{\prime}$ dir [3]. AB plastik atıkların atılmasıyla mücadele etmekte bunun akabinde yeniden kullanım ve geri kazanım uygulamalarını artırma çalışmalarını sürdürmektedir. Gelişmekte olan ülkelerde ise hala 
konvansiyonel

depolama

yapılmaktadır. $\mathrm{Bu}$ ülkelerde plastik tüketimi dünya ortalamasının üzerinde olduğu belirtilirken, bunun nedeni olarak da hızla değişen endüstriyel ve ekonomik gelişmeler gösterilmektedir [25].

Plastik atıkların geri kazanılması için mevcut teknolojiler yeterli olsa da, 2050 yılında dünya nüfusunun 9 milyar olacağı düşünüldüğünde plastik üretimine ihtiyaç oldukça artacaktır. $\mathrm{Bu}$ durumun beraberinde getireceği en büyük olumsuz etkilerin başında da plastik atık miktarındaki artış gelecektir [1]. Danimarka gibi en yüksek yakma tesisine sahip Avrupa ülkelerinde plastik atıklara yakılma (\%76) işlemi uygulanmaktadır. Standart kriterlere göre yakma tesisi inşa edilmesine rağmen bazı çevresel olumsuzluklar ortaya çıkabilmektedir. Bunlar, plastik atıklardan enerji eldesi net $\mathrm{CO}_{2}$ emisyonunu artirmakta ve bunun yanı sıra çok fazla tehlikeli ve toksik bileşik içeren kül ve cürufun depolama sahalarına gitmesi de çevresel problemlere neden olmaktadır
[4]. Böylece çevreye dayanıklı plastik atıkların depolanmasını önlemek ve sürdürülebilir bir çevre yaratmak için biyoplastik üretimi önem kazanmaktadır. Avrupa Birliği, biyoplastikleri biyolojik kökenine biyobozunur niteliğine veya her iki özelliğe birden sahip plastik materyali olarak tanımlamaktadır [5]. Bu tanıma göre, yenilenemez enerji kaynaklarının daha az tüketimiyle sonuçlanan biyoplastik ambalaj üretiminde yenilenebilir nişasta kullanılması ile polystiren ambalajiyla karşılaştırıldığında daha az sera gazı emisyonu oluşmaktadır [5].

\section{Biyoplastik}

Üretiminin

\section{Türkiye'deki Durumu}

Ülkemizde

ihtiyaç

doğrultusunda sürekli gelişme içinde olan plastik sektörü son zamanlarda oldukça iyi bir seviyeye gelmiş durumdadır. Avrupa ülkelerinde bulunan plastik sektörüne yaklaşmış durumda olan Türkiye birçok alanda plastik endüstrisi ile çalışmalar yapmaktadır. İnsanlar için vazgeçilmez olan plastik ürünler dayanıklı ve ekonomik olmalarından 
dolay1 birçok kişinin her alanda kullandığı ürünler arasındadır. Ancak geleneksel

plastiklerinin hammaddelerinin sağlam olması plastiklerin sağlam olmasına neden olurken aynı zamanda doğa da çözünmesi de oldukça güç hale gelmektedir [6]. Günümüzde ambalaj, tarım, otomotiv, ev aletleri, tüketici elektroniği alanlarında kullanılan biyoplastikler yıllık toplam plastik üretiminin yalnızca yüzde 1.5 'ini karşılamaktadır. Dünya genelinde 325 milyon ton fosil kaynaklı plastik üretilirken, 5 milyon tonunu biyobazlı plastikler oluşturmaktadır. 2014 y1lında biyoplastik pazarının \%60'ından fazlasını Kuzey Amerika ve Avrupa oluşturmuştur. Araştırmalar ise 2020'ye kadar Asya Pasifik bölgesinin Avrupa ve Kuzey Amerika'dan sonra en büyük biyoplastik tüketicisi olacağını göstermektedir. Gelişen teknolojiyle birlikte özellikle son beş y1lda ciddi bir artı̧̧ gösteren dünya biyoplastik üretiminin 2020 yılına kadar y1llık \% 14.8 artışla miktar bazında 15 milyon ton ve değer bazında 30,8 milyar dolara ulaşacağı tahmin edilmektedir [7].

Biyoplastik teknolojisi günümüz insanının bilincinde olduğu bir konu haline gelmiştir. İlk endüstriyel üretimine 1980'li yılların başlarında başlanan biyobozunur plastiklerin üretimi [8], günümüzde yüksek hızla değişen teknolojik gelişmelere bağl1 olarak gelişen teknolojisiyle birlikte Avrupa ülkelerinde $\% \quad 20^{\prime}$ lik bir gelişme kaydetmiştir. Buna karşın ülkemizde de plastik endüstrisinde önemli bir yere sahip olmaya başlayan biyoplastik ürünler, pazar açısından da oldukça önemli bir pay almaktadır [12].

Üretimlerinin başlangıcından 1990'l1 yılların sonuna kadar biyoplastikler biyoçözünürlük başlığı altında ilerlemekteydi. 2000'li y1llara gelindiğinde biyoplastiklerin karbon tüketimini azaltacağı yönünde fikirler ortaya çıkmaya başlamıştır. 2010 yllinda ise biyoplastiklerin de plastik oldukları ön plana çıkmıştır [28]. Yaklaşık 45 yıllık bu süreçte 
biyoplastiklerin üç değeri önemli kıldığı anlaşılmıştır [11]:

1. Çevresel ve sürdürebilirlik,

2. Petrokimya bazlı plastiklere göre daha istikrarlı fiyat,

3. Petrol ve doğalgaz ihracatına olan bağımlılığın azalması.

\section{Biyoplastiklerin Üretim Yöntemleri}

Genellikle biyoplastikler şeker, misır ve patates gibi [9] protein, lipit ve polisakkaritleri içeren yenilenebilir kaynaklardan [10] ya da bazı mikroorganizmalardan, alglerden ve mantarlardan üretilmektedirler [11]. Son zamanlarda ise bitki ya da hayvansal üretimin yanında, biyolojik köken ve petrol monomerlerinin birleştirilerek üretildiği biyoplastikler de gündeme gelmiştir. Petrol kökenli plastiklerin ylllı üretimi 2015 'de 300 milyon tondur. Petrol ya da kimyasal türevli olmayan ve tamamen biyolojik kaynaklı plastik üretimi, biyoçözünürlüğün yüksek olmasından dolayı daha sürdürülebilir bir üretim şekli olarak görülmektedir. Bu nedenle pek çok ülke biyosferden hemen bertaraf edilebilecek, yeni ve yaygin kullanıma sahip materyallerin keşfi ve üretilmesi için özel programları teşvik etmekte ve bu kirleticilerin dönüşümünü kolaylaştıracak stratejiler geliştirmektedir.

Bunlar arasinda biyoteknoloji uygulamalar sonucunda geliştirilmiş olan biyolojik tabanl1, kolay çözünebilen ve yenilenebilir özelliğe sahip biyoplastikler akla gelmektedir [12]. Biyoplastikler üretim yöntemlerine göre 3'e ayrılmaktadırlar (Şekil 1).

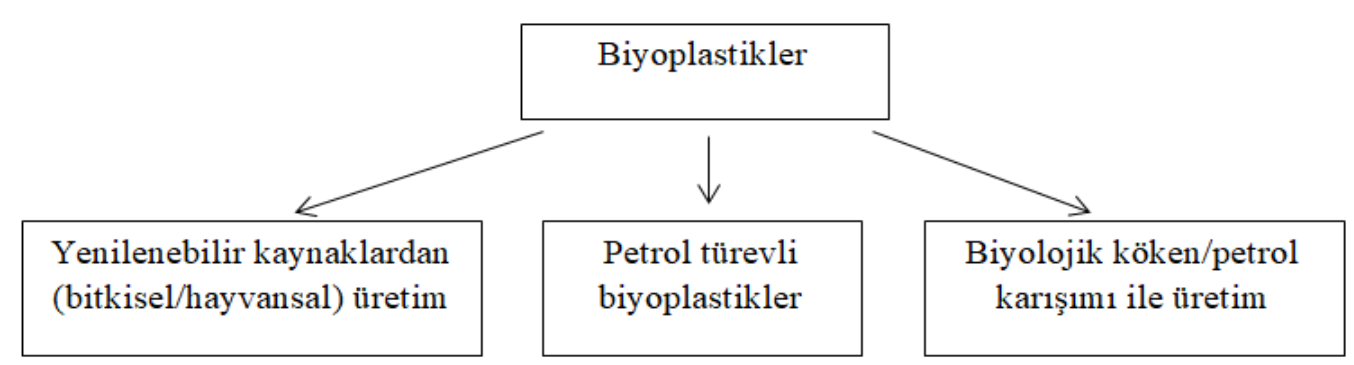

Şekil 1. Biyoplastiklerin üretim yöntemlerine göre sinfflandırllması [27]. 
- Petrol türevli biyoplastikler; petrol türevli monomerlerden sentezlenen ancak biyolojik olarak parçalanabilen biyoplastiklerdir. Polikaprolakton (PCL) ve polibütülenadipattereftalat (PBAT) gibi biyoplastikler bu gruba dahil edilmektedir [11].

\section{- Biyolojik kökenli petrol karşımı} ile üretilen biyoplastikler; biyolojik kökenli kaynaklar ile petrol kökenli kaynakların monomerlerinin kombinasyonu ile elde edilen polimerlerdir. Örneğin, bu gruba dahil olan politrimetilentereftalat (PTT), biyolojik tabanlı 1,3-propanediol ve petrol türevli terefitalikasitin birleştirilmesi ile üretilmektedir [11].

- Yenilenebilir kaynaklardan biyoplastik üretiminde; nişasta (misır, patates, arpa, buğday, şeker pancarı gibi), selüloz (odun gibi), lignin, protein (buğday gluteni)ve yağ gibi bitkisel hammaddeler kullanılmaktadır [11]. Biyoplastik kaynaklarının petrol kökenli ve biokökenli olarak sınıflandırılması Tablo 1.'de gösterilmiştir.

Tablo 1. En çok kullanılan biyoplastiklerin sınıflandırılması [1].

\begin{tabular}{llll}
\hline & Kaynak & Adı & Kısaltma \\
\hline Biyoplastikler & Petrol kökenli & Polybütilensuccirate & PBS \\
& & Polycaprolactone & PCL \\
& Polyethylenesuccinate & PES \\
& Polybutyrateadipateterephthalate & PBAT \\
& Polyamide & PA \\
& & Polyethylere & PE \\
& & Poly(ethyleneterephtalate) & PET \\
& & polypropylene & PP \\
\hline \multirow{3}{*}{ Biyoplastikler } & Biyo-kökenli & Poly (laktik asit) & \\
& & polyhydroxyalkanoate & PLA \\
& & Starchplastics & PHA \\
\hline
\end{tabular}


celluloseesters

Bio-polyethylene

Bio-PE

Bio-polyethyleneterephtalate

Bio-PET

Bio-polyamide

Bio- PA

Yenilenebilir kaynaklardan elde edilen biyoplastik grubunda yer alan biyoplastik türleri polilaktik asit (PLA), polyhydroxyalkanoate (PHA) ve polihidroksibütirat (PHB)'dır. Biyoplastikler arasında PLA ve PHA üretim ve kullanım açısından lider konumundadır. $\mathrm{Bu}$ polimerler bitkisel nişasta ile birlikte elastiki film, enjeksiyon kalıplı objeler ve zirai malç gibi kısa ömürlü ürünlerin yapımında kullanılmaktadır [1]. Biyoplastik üretiminde en çok yararlanılan biyolojik kaynaklardan biri de bakterilerdir. Sinırlı azot ve fazlaca karbon kaynağı varlığında bazı mikroorganizmaların intraselüler depo materyali olarak PHA sentezlediği bilinmektedir. PHA \%100 biyolojik olarak parçalanabilir bir biyoplastik türü olarak karşımıza çıkmaktadır [11]. Bio-kökenli ve petrol kökenli plastiklerin farklı durumlarda özelliklerinin karşılaştırmalı gösterimi Tablo 2'de verilmiştir.

Tablo 2. Bio-kökenli ve petrol kökenli plastiklerin özelliklerinin karşılaştırılması [2].

\begin{tabular}{lll}
\hline & Biyoplastikler & Petrol plastikleri \\
\hline Yenilenebilir & Evet veya kısmen & Hayır \\
Sürdürülebilir & Evet & Hayır \\
Çevrede bozunma & Biyoparçalanabilir/kompostlanabilir & Polimer oksidasyon ile \\
& & bazı parçalanabilirlikler \\
Sera etkisi & Genellikle düşük & Yüksek \\
Fosil yakıt kullanımı & Genellikle düşük & Yüksek \\
Tarıma elverişli & Şuanda düşük & Asla \\
arazi kullanımı & & \\
\hline
\end{tabular}


Çevrede plastiklerin birikimi ile ortaya çıkan sürdürülebilir biyoplastik üretimi endüstrileri zorlamıştır. $\quad 2014 \quad$ verilerine bakıldığında, 1.7 milyon ton biyoplastik üretilmiştir [13]. Biyoplastik üretiminin 2018 y1lında yaklaşık 6.2 milyon ton olacağ düşünülmektedir. 2012'de PLA ve nişasta katkılı plastik kullanımı toplam tüketimin sirasıyla \%47 ve \%41'i kadardır [1]. Biyoplastiklerin çevre dostu olmalarının yanı sıra yüksek üretim maliyeti ve zayıf mekanik özellikleri gibi dezavantajları bulunmaktadır. Yüksek üretim maliyetinin olumsuz yönü tarımsal kökenli atıklar gibi yenilebilir kaynakların düşük maliyetle biyoplastik üretiminde kullanılmasına olanak sağlamaktadır [1].

Endüstri, üretim ve paketleme gibi birbirinden farklı amaç ve süreçlerde kullanılan plastiklerden kaynaklanan atıkların nihai depolanma alanları nehir, göl, deniz gibi sucul ortamlardır. Özellikle parçalanma olarak tanımlanan süreç sonrasında büyük plastik parçalarının küçük plastik parçacıklarına dönüşmesiyle sucul ortamlarda yüzer hale gelen plastik atıkların balıkçılık, hidroelektrik santrallerinin işletilmesi, sulama ve diğer kamu çalışmalarına yönelik tehditleri giderek artmaktadır [11]. Üstelik plastiklerin \%99'undan fazlasının fosil yakıt kökenli olması nedeniyle parçalanma hızlarının oldukça düşük olması (yüzlerce yıl) ve dolayısıyla doğal çevresel ortamlardaki (su, toprak gibi) birikme hızlarının ayrışma hızlarından oldukça yüksek kalması, zaten yeryüzünde sınırlı olan yenilenemez doğal kaynaklara olan baskıyı her geçen gün artırmaktadır. Yenilenebilir doğal kaynaklardan üretilen biyolojik olarak parçalanabilen plastikler, kirlilik yükünü azaltarak yenilenemez doğal kaynakların korumasina ve sürdürülebilir kullanımına katkıda bulunmaktadır [11].

\section{Biyoplastiklerin Avantaj ve \\ Dezavantajları}

Birçok ülkede biyoplastik üretimi yapılmakla birlikte biyoplastiklerin gelecekte plastiğin yerini alacağını düşünülmektedir. $\mathrm{Bu}$ 
nedenle biyoplastikler olumlu ve olumsuz etkileriyle (yönleriyle) birlikte ele alınmalıdır. Biyoplastiklerin avantajları şu şekilde siralanabilir:

\section{$\checkmark$ Petrole olan bağımlılığın}

azaltılması; petrol ve türevlerinden üretilen plastiğin aksine, biyoplastiklerin yenilenebilir hammaddelerden üretilmesinin toplumların ve üretimin petrole olan bağımlılığını azaltacağı belirtilmektedir. Ayrıca, ekonomik olarak rekabetten ileri gelen petrol fiyatındaki dalgalanmaların da dolaylı olarak azalacağı düşünülmektedir.

$\checkmark$ Enerji verimliliği; biyoplastiklerin üretimi sırasında, geleneksel plastiklere oranla $\% 65$ daha az enerji tüketildiği ileri sürülmektedir.

$\checkmark$ Daha az sera gazı emisyonu; biyoplastiklerin üretim sürecinde geleneksel plastiklerin üretim sürecine oranla daha az sera gazı emisyonları ortaya çıkmaktadır. Yu ve Chen (2008) yaptıkları bir çalışmada $1 \mathrm{~kg}$ biyoplastiğin üretimi sırasında $0.49 \mathrm{~kg}$ karbondioksit üretildiğini, $1 \mathrm{~kg}$ geleneksel plastiğin üretiminde ise 2-3 kg karbondioksit gazı üretildiğini saptamışlardır. Bunun da küresel ısınmayı $\% 80 \quad$ azaltacağı ileri sürülmektedir.

$\checkmark$ Çevre dostu; biyoplastiklerin toksik madde içermemeleri sebebiyle geleneksel plastiklere göre çevre dostu olduğu belirtilmektedir.

Biyoplastiklerin dezavantajları ise şöyle sıralanabilir:

Yüksek fiyat; biyoplastik maliyetlerinin, plastiklerden daha fazla olduğu belirtilmektedir. Fakat biyoplastik üretiminin yaygın olarak endüstriyel miktarlarda daha fazla gerçekleştirilmesi ile gelecekte maliyetin de azalacağı düşünülmektedir.

$\checkmark$ Geri dönüşüm; son zamanlarda yapılan araştırmalarda biyoplastiğin farklı yapısının, geri dönüşümünde problemlere neden olduğu belirtilmiştir. Örneğin kızıl ötesi ışın ile çalışan çöp ayrıştırma sistemlerinde biyoplastikler ayrıştırılamamakta, diğer plastiklerle karışmakta ve ayrılması istenen plastiği kirlettiği ileri sürülmektedir. 


\section{Kullanılan}

hammaddelerin

özellikleri; yenilenebilir kaynaklardan üretilen biyoplastiklerin ham madde rezervlerini azaltabilecek olması önemli bir eleştiri olarak ortada durmaktadır. Günümüzde nişasta ve protein gibi insan besini olan hammaddelerin biyoplastik üretiminde kullanılmasının artan dünya nüfusunun gelecekteki besin ihtiyacındaki açığ1 artırabileceği öngörülmektedir.

\section{Biyobozunabilirlik}

Biyobozunur plastikler, doğal aerobik (kompostlama) ve anaerobik ortamlarda (atık gömme alanı) ayrışacak olan plastiklerdir. Plastiklerin biyobozunumu ortamdaki mikroorganizmaların, plastik filmlerin moleküler yapısını çevreye daha az zararlı, ağır, humus benzeri bir malzeme üretecek şekilde metabolize etmeleri sağlanarak gerçekleştirilebilir [14]. Şişirme maddeleriyle birleştirilmiş biyoaktif bileşiklerin kullanımı 1sı ve nemle birleştikleri zaman plastiğin moleküler yapısını genişleterek biyoaktif bileşiklerin plastiği metabolize ve nötralize etmelerini sağlar. Son yıllarda birçok çalışma yapılmış ve biyoparçalanabilir plastikler farklı çevrede çalışılmıştır. PLA ve PHA parçalanması diğer polimerlerden PCL ve PES'den daha çok çalışılmıştır. Ortam pH, nem, oksijen içeriği ve sıcaklık gibi çevresel koşulların biyo- parçalanmasında çok önemli rol oynadığını ortaya koymaktadir. Ayrica mikroorganizmalar da farklı ekosistemlerde biyoplastiklerin parçalanmasından sorumludurlar. Gerçekte mikroorganizmalar enzimler aracılığıla biyopolimerlerin biyodegradasyonunu katalizlerler. Toprak, kompost, deniz, nehir ve diğer ortamlardan izole edilen mantar ve bakteri türleri biyoplastikleri en son aşamada su, karbondioksit $\left(\mathrm{CO}_{2}\right)$, metan $\left(\mathrm{CH}_{4}\right)$ ve hücresel biyokütleye dönüştürürler $[15,16,17,18,19,20]$.

\section{Biyobozunurluk Standartları}

Amerika Birleşik

Devletleri'nde, Amerikan Test ve Malzeme Derneği (ASTM) uluslararası biyobozunurluk standartlarını belirleyen yetkili birimdir. $\quad \mathrm{Bu}$ standartların denetlenmesi sorumluluğu da çevrede 
bozunur plastikler ve biyo tabanlı ürünler komitesi D20.96'ya düşmektedir. Mevcut ASTM standartları standart şartnameler ve standart test yöntemleri olarak tanımlanır. Standart test yöntemleri, plastikler üzerindeki belirli biyobozunurluk testlerinin kolaylaştırılması için belirli test parametrelerini belirlerken standart şartnameler bir geçer-kalır olarak ifade edilen senaryoyu üretmektedir.

Hali hazırda, çoğunlukla kompostlama tipi ortamlardaki biyobozunur plastikleri ele alan bu türden üç ASTM Standart şartnamesi bulunmaktadır:

$\checkmark$ Kompostlanabilir plastikler için ASTM D6400-04 Standart Şartnamesi

Kağıt ve diğer kompostlanabilir substratlar üzerine kaplama olarak kullanılan biyobozunur plastikler için ASTM D6868 - 03 Standart Şartnamesi

\section{Deniz Ortamında yüzmeyen} biyobozunur plastikler için ASTM D7081-05 Standart Şartnamesi.

Bunların dışında biyoesaslı malzemeler için ASTM D6866 yöntemi biyoplastiklerin biyolojik olarak türetilmiş içeriklerinin belgelendirilmesi için geliştirilmiştir [14]. Uygun şartlar altında biyobozunur plastikler mikroorganizmaların onlanı metabolize edebilecekleri noktaya kadar bozunabilirler. Petrol bazlı bozunur plastiklerin bozunması daha önce depolanmış olan karbonun karbondioksit olarak salınmasına neden olur. Toprak, kompost, deniz ve diğer sucul ortamlar gibi farklı çevresel koşullarda biyoplastiklerin biyobozunabilirliği üzerine çalışmalar yapılmıştır [14].

$$
\text { ASTM D-5488-94d }
$$

standardına göre biyobozunur ifadesi, mikroorganizmaların enzimatik mekanizmalarıyla plastik materyalinin karbondioksit, metan, su, inorganik bileşiklere parçalanabilir anlamına gelmektedir. Kompostlanabilme ise maddenin kompost kullanılarak biyolojik olarak yıkılabilmesidir. Biyolojik olarak parçalamak ise organik bir maddenin biyolojik aktivite yardımıyla, büyük çoğunlukla mikroorganizmaların enzim 
aktiviteleriyle parçalanmasıdır. $\mathrm{Bu}$ da maddenin kimyasal yapısında önemli değişikliklere neden olur. Ortaya çıkan son ürünler oksijen varlığında karbondioksit, yeni biyokütle ve su iken, oksijen olmayan ortamlarda ayrışma ürünü metan olmaktadır. Bu da European Standard EN 13432:2000 standardında tanımlanmıştır [13]. Fakat kullanılan standarda göre, ASTM ya da EN, kompostlanabilirlik seviyesini belirlemek için farklı koşulu (nem ve sicaklık döngüsü) değerlerinin kullanılmasını gerektirmektedir. $\mathrm{Bu}$ durum da farklı standart koşullarında elde edilen sonuçların karşıışaştırılmasını zorlaştırmaktadır [21]. Bunlara ek olarak mineralizasyon miktarı ve biyobozunma sonrası kalan maddenin doğası da önemlidir. Toksik artık maddelere sahip kirleticilerin durumları ve bu ürünlerin biyoparçalanmaları için gerçekleşen kimyasal reaksiyonlar ayrışmanın gerçekleştiği ortamdaki diğer canlıların (flora ve fauna) gelişimini inhibe edebilmektedir. Aslında en önemli nokta oluşan bu ürünlerin çevreye zararının belirlenmesidir. $\mathrm{Bu}$ değer de eko-toksiklik olarak adlandırılmaktadır [21].

\section{Kompostlanabilirlik}

Kompostlama, organik bir maddenin kompleks bir mikroorganizma grubunun aktivitesiyle toprak yapısında humus benzeri madde ve $\mathrm{CO}_{2}$ 'e dönüştürme prosesidir. ASTM tarafından kompostlanabilen plastik “Görsel olarak ayırt edilemeyen veya toksik atık bırakmayan ve diğer bilinen kompostlanabilir maddeler ile $\mathrm{CO}_{2}$, $\mathrm{H}_{2} \mathrm{O}$, inorganik bileşikler ve biyokütle oluşturarak kompostlama esnasında biyolojik proseslerle bir plastiğin parçalanması" olarak tanımlanır [22]. ASTM, bir plastiğin kompostlanabilir olarak adlandırılması için üç kriterin yerine getirilmesi gerektiği belirtmiştir:

a. Biyobozunma: Selüloz ile aynı hızda karbondioksit, su ve biyokütleye ayrışma.

b. Parçalanma: Malzeme kompost içinde fark edilebilir değildir, yani gözle görülmez ve elenmesi gerekmemelidir. 
c. Eko-zehirlilik: Biyobozunma hiçbir zehirli madde üretmez ve gübrelenerek bitki gelişimini desteklemektedir [21].

Özetle kompostlanabilir plastik biyolojik olarak parçalanabilir fakat bir biyoparçalanan plastik her zaman kompostlanamamaktadır. Farklı biyoplastiklerin biyodegredasyonu için mikroorganizma toplulukları olarak kompost kullanılması üzerine son yıllarda çalışmalara başlanmıştır. Hem biyo-kökenli hem de petrol kökenli biyoplastikler (PLA, PHA, nişasta kökenli, PBS, PES ve PCL) spesifik çevresel koşullarında (sıcaklık, pH ve nem içeriği) kompost tarafindan biyolojik parçalanmaya duyarlıdır [21].

Evsel ve endüstriyel kompostlar arasındaki koşul farklılıkları biyoplastiklerin biyoparçalanmasında önemli farklıliklara neden olmaktadir. Evsel kompost koşulları altında PLA biyoplastiğin biyodegradasyon çalışmaları çok yavaş biyolojik parçalanma olduğunu göstermektedir. Daha önce belirtildiği gibi yenilenebilir kaynaklar biyoplastikleri üretmek için uygulanabilmektedir. Örneğin; yüksek protein içeriğine sahip maddelerin ilavesiyle biyokompozitlerde çözünen şeker içeriği artırılarak biyoplastiklerin biyoparçalanabilirliği artmaktadır. PLA biyoplastiğindeki misır varlığı kompostta biyodegradasyonu artırmaktadır. Bunun nedeni misırın yüksek biyoparçalanabilir özelliğe sahip bir madde olmasıdır. Böylece mikroorganizmalar maddeyi parçalar ve PLA parçalanması daha etkin hale gelir. Selüloz asetat (CA) biyoplastikler tarımsal atıklardan üretilmişlerdir. Önceki yapılan çalışmalarda, düşük maliyetli fiber flax ve pamuk linterlerden yapılan CA biyoplastiklerin parçalanması on dört günlük kompostlama sonucu sırasıyla $\% 44$ ve \%35 olarak tespit edildiği belirtilmiştir [21].

\section{Sonuç ve Öneriler}

Plastik kullanımındaki artışın her geçen gün artması çevresel problemleri de beraberinde getirmektedir. Günümüzde petrol 
fiyatlarının yüksek olması, mevcut petrol rezervlerindeki azalma, bununla birlikte sera gazlarıdaki artış nedeniyle biyolojik esaslı geliştirilen yenilenebilir biyoplastikler, gübrelenebilir ve biyoparçalanabilirlik gibi özellikleri barındırdığı için çevre dostu ürünler olarak kullanımda önemli bir yere sahiptir.

Konvansiyonel plastiklerin çevreye olumsuz etkilerinin yanı sıra, zayıf parçalanabilirlikleri ile fosil yakıt kaynaklarındaki azalmaya bakıldığında plastiklere alternatif olacak ürünlerin arayışı hız kazanmalıdır. Plastiklerin aşıı üretiminin sonucu olarak gelecek plastik atık yükü de yalnız çevreyi değil insan sağlığını da olumsuz yönde etkilemektedir. Doğada petrol bazlı plastiklerin bozunması yaklaşık olarak 1000 y1l iken, alternatif olarak kullanılacak olan biyoplastiklerin doğaya karışması 1 ile 6 ay arasında olması çevre sağlığı açısından oldukça önemlidir. Üretilecek olan bio-kökenli plastiklerin yenilenebilir kaynaklardan eldesi ile geleceğe olumlu yönde kazanımlar sağlanacaktır.
Türkiye'de de kullanılmaya başlanılanan

biyoplastiklerin avantajlarının yanında dezavantajları da değerlendirilip, olumsuz yanları en aza indirilerek yaygın kullanımı hedeflenmelidir. Biyoplastiklerin çevreye zararlı olmamaları konusunda ASTM kurumu tarafindan oluşturulan standartların uygulamada eksik kaldığ düşünülmektedir. $\mathrm{Bu}$ nedenle, ülkemizde de atık yönetimi vb. gibi yönetmeliklerin, standartların yanında biyoplastiklerin kullanımları üzerinde de çalışmaların yapılması gerekmektedir. Ülkemizde ilerleyen zamanlarda biyoplastik endüstrisinin gelişmesi ile yeterli ekonomik seviyeye ulaşıldığında biyoplastik hammaddelerin üretimine de imkan sağlanmış olacaktır. Yüksek tarım potansiyeline sahip olan ama petrolde dışa bağımlı olan ülkemiz biyoplastik kullanımının yaygınlaşması halinde, gelecekte plastik üretimi ve kullanımı konusundaki çevre dostu senaryolar ile kayda değer bir ilerleme sağlayacaktır.

\section{Kaynaklar}

[1] Emadian M. S., Onay T., Demirel B, 2017. Biodegradation of bioplastics 
in natural environments, Waste Management, 59: 526-536.

[2] Harding K. G., Gounden T., Pretorious S, 2017. "Biodegradable" plastics: A myth of marketing?, Procedia Manufacturing, 7: 106-110.

[3] EU, 2013. Green Paper on a European Strategy on Plastic Waste in the Environment.

[4] European Commission, 2011. Plastic Waste in the Environment, Final Report.

[5] European Bioplastics, 2017. "What are bioplastics?".

https://www.european-

bioplastics.org/bioplastics/ 13 Ekim

2018'de erișildi.

[6] Kumru M, 2013. "Biyoplastik pazarının Türkiye'deki durumu nas1l?',

http://www.biyoplastik.net/2013/02/bi yoplastik-pazarnn-turkiyedeki-

durumu.html, 28 Mayıs 2018'de erişildi.

[7] Gülşen H., Akin B, 2017. Biyoplastikler ve çevresel etkileri, Academia Journal of Engineering and Applied Sciences, 1,3: 1-9.

[8] Vroman I., Tighzert L, 2009. "Biodegradable Polymers", Materials, 2: 307-344.

[9] Sarasa J., Gracia J. M., Javierre C, 2008. Study of the biodisintegration of a bioplastic material waste, Bioresource Technology, 100: 37643768.

[10] Siracusa V., Rocculi P., Romani S., Dalla Rosa M, 2008. Biodegradable polymers for food packaging: a review, Trends Food Science Technology, 19: 634-643.

[11] Arıkan E., Özsoy H. D, 2014. Bitkilerden biyoplastik üretimi, Bursa Tarım Kongresi, Türkiye.

[12] Özdemir N., Erkmen J, 2013. Yenilenebilir Biyoplastik Üretiminde Alglerin Kullanımı, Karadeniz Fen Bilimleri Dergisi / The Black Sea Journal of Sciences 3(8): 89-104.

[13] European Bioplastic, 2015. http://en.europeanbioplastics.org/technology-materials/ Son Erişim Tarihi: 13/10/2018.

[14]https://yesilintakipcisi.wordpress.c om/2011/02/19/biyocozunur-plastik standartları/, 28 Mayıs 2018'de erişildi.

[15] Malinconico M., Immirzi B, Santagata G., Schettini E., Vox G. and Scarascia Mugnozza G, 2008. "An overview on innovative biodegradablematerials for agricultural applications". Progress in polymer degradation and stability research. Editor: Moeller, H.W. New York: Nova Science. 
[16] Malinconico M., Immirzi B., Massenti S., La Mantia F.P., Mormile P. and Petti L, 2002. "Blends of polyvinylalcohol and functionalized polycaprolactone. A study of the melt extrusion and post-cure of films suitable for protected cultivation", Journal of Material Science, 37: 49734978.

[17] Kyrikou I., Briassoulis D, 2007. "Biodegradation of agricultural plastic films: A critical review", Journal of Polymers and the Environment, 15: 125-150.

[18] Imam S.H., Cinelli P., Gordon S.H., Chiellini, E, 2005. "Characterization of biodegradable composite films prepared from blends of poly (vinyl alcohol), cornstarch and lignocellulosic fiber", Journal of Polymers and the Environment, 13(1): 47-55.

[19] Tzankova Dintcheva N., La Mantia F.P, 2007. "Durability of a starch-based biodegradable polymer", Polymer Degradation and Stability, 92: 630-634.

[20] Kijchavengkul, T., Auras, R., Rubino, M., Ngouajio, M., Fernandez, R.T., 2008a. "Assessment of aliphaticaromatic copolyester biodegradable mulch films, Part I: field study", Chemosphere, 71: 942-953.

[21]http://www.bioplasttr.net/compost. html , 28 Mayıs 2018'de erişildi.
[22] ASTM D 5988-03, 2003. Standard test method for determining aerobic biodegradation in soil of plastic materials or residual plastic materials after composting. ASTM International, West Conshohocken, PA USA.

[23] Korun, S, 2019. Plastik Atıkların Kimyasal Bozundurma ile Faydalı Ürünlere Dönüşümü için Katalizör Geliştirilmesi, Yüksek Lisans Tezi, İnönü Üniversitesi, Malatya.

[24] Pathak, S., Sneha, C.L.R., Mathew, B. B, 2014. Bioplastics: its timeline based scenario \& challenges. J. Polym. Biopolym. Phys. Chem. 2: 84-90.

[25] Muenmee, S., Chiemchaisri, W., 2016. Enhancement of biodegradation of plastic wastes via methane oxidation in semi-aerobic landfill. Int. Biodeterior. Biodegr. 113: 244-255.

[26] Yu, J., Chen L. X. L, 2008. The Greenhouse Gas Emissions and Fossil Energy Requirement of Bioplastics from Cradle to Gate of a Biomass Refinery, Environ. Sci. Technol., 42: 6961-6966.

[27] Reddy M. M., Vivekanandhan S., Misra M., Bhatia S. K., Mohanty A. $\mathrm{K}$, 2013. Biobased plastics and bionanocomposites: Current status and future opportunities, Progress in Polymer Science 38(10-11): 16531689. 
[28] Kaplancalı K, 2014. Biyoplastik Malzemelerin Ambalaj Uygulamaları, Uluslararası Plastik Ambalaj Teknolojileri Kongresi, 17 Eylül 2014, İstanbul. 